\title{
Agroedutourism and Ecopreneurship Activities on the Organic Farming Practices in Lawang, Malang Regency, East Java, Indonesia
}

\author{
Ayu Raisa Khairun Nisa' ${ }^{1}$, Setijono Samino ${ }^{2}$, Endang Arisoesilaningsih ${ }^{2}$ \\ ${ }^{1}$ Master Program of Biology, University of Brawijaya, Malang, Indonesia \\ ${ }^{2}$ Department of Biology, University of Brawijaya, Malang, Indonesia
}

\begin{abstract}
Five farmer groups in Lawang, Malang Regency, East Java Provinces, established organic agricultural practices almost two decades. They were visited frequently for farmer benchmarking activities; therefore they had planned to develop agroedutourism. The aims of this research were to identify potential organic farming activities as agroedutourism attractions as well as farmer ecopreneurship, to find out the existing agroedutourism facilities profile and to propose some strategies for further sustainable development. The data were gathered by interviewing key person of each farmer group in Lawang. Their agroedutourism profiles compared with a developed local agro-tourism using gap analysis. Farmer groups offered some distinct attractions and become their strengths such as out door activities in the organic perfumed and pigmented rice field, fruits and vegetable garden, zero waste management, biological pest control and healthy agricultural products. Establishment of this agroedutourism would be advantageous to lesson sharing among farmers and students, to be ecopreneur activity shown by an effective market system, to show real benefits of healthy agro-ecosystem and its products, as well as to show promising green business or ecopreneurship. Collaboration among them would improve available attractions and length of visit. Moreover, the results showed that $80 \%$ of farmer groups were visited regularly 5-10 times per month by potential visitors such as other farmer groups, house wives, staffs of agricultural departments and students. All farmer groups planned to develop agroedutourism; however the policy was only issued by $60 \%$ of farmer groups. Most of farmer groups showed a high variability in providing edutourism tours and guides. For sustainable development, farmer groups should provide more interesting attractions and facilities, develop their human resource, net working, and public promotion.
\end{abstract}

Keywords: agroedutourism, attraction, ecopreneurship, farmer groups.

\section{INTRODUCTION}

Conventional farming is generally characteriz-ed by extensive use of pesticides, fertilizers, and external energy inputs; high labor efficiency; large capital investments in order to achieve a high production and efficient management technology; large-scale farms; single crops/row crops grown continuously over many seasons; uniform high yield hybrid crops; and rapid technological innovation [1]. Conventional farming contributes many negative impacts such as soil erosion, nutrient run off, loss of organic matter, impairment of environmental quality and pollution of natural water by agricultural synthetic pesticides or fertilizer residues [2]. Pests and diseases become more difficult to be controlled as they become resistant to chemical pesticides. In addition, the prolonged use of chemical substances could stay in the soil for a long time and enter the food chain where they accumulate in the bodies of

\footnotetext{
* Correspondence address:

Ayu Raisa Khairun Nisa'

Email : chabio29@gmail.com

Address : Master Program of Biology, University of Brawijaya, Jl. Veteran Malang 65145
}

plants, microbes, animals and humans, as well as causing health problems [3].

Several negative impacts of conventional farming system trigger people awareness on healthy life and idea of back to nature. Organic farming system starts to gradually replace the conventional ones due to increasing demands of organic food and growing environmental concerns. Indonesian Agricultural Ministry established program of "Go Organic 2010" toward a leading organic producer in the world. Unfortunately, organic farming in Indonesia is still less developed and lack of significant contribution to agribusiness with limited commodities [4]. Generally, only old farmers show willingness to practice organic farming due to this farming system is completely relevant to their previous local knowledge. Based on traditional farming system, farmers produce high quality products, use their own fertilizer and minimize in tilling the soil. This condition also worsened by the youth who does not interested and proud become farmer anymore, whereas agriculture is consistently important sector in Indonesian economic development and contributes a significant role to establish national food security. 
During Indonesian economic crisis in 1997-1998, farmers faced a great difficulty to get chemical fertilizers and pesticides. It challenged rice farmers in Lawang to convert their farming system to organic one in 1998. Even now, in Sumber Ngepoh Village only has two farmer groups consisting almost a hundred farmers who cultivate organic rice. Actually, organic farming system has been developed in harmony with the nature without harming the environment as well as people who live or work in it. It creates a healthy balance between nature and farming, where crops and animals grow, while pests and weeds are controlled to an acceptable level for high yield benefits [3]. Studies reported that organic farming is able for increasing the level of total nitrogen in soil and preventing nutrients leaching [5].

Organic farming is not only eco-friendly but also provides a great opportunity to start green business for farmer. Therefore, farmer groups in Lawang developing varied organic products such as perfumed and pigmented rice, vegetable, fruit and livestock. In the beginning, they faced many difficulties in marketing their products because distributor fixed the price and monopolized the marketing. In addition, organic products are consumed by limited people due to less awareness on the importance of healthy food. Furthermore, farmer groups tried to improve their activities to become tourist destination through agroedutourism. They are frequently visited and become reference site for student to aware the farmer's potency and importance of conversion conventional farming toward organic farming. Therefore, aims of this research were to identify potential organic farming activities as agroedutourism attractions as well as farmer ecopreneurship, to find the existing agroedu-tourism facilities profile and to prepare some strategies for further sustainable development.

\section{MATERIALS AND METHODS}

This research was carried out in Sumber Ngepoh Village and Wonorejo Village, Lawang, East Java Province, Indonesia (Fig. 1), on August 2013 to March 2014. Lawang is a gateway of Malang City with elevation 485-560 meters above sea level, temperature $22-32^{\circ} \mathrm{C}$ and a precipitation $349 \mathrm{~mm}$.month ${ }^{-1}$ [6]. Most farmers in Sumber Ngepoh Village had planted rice using inorganic pesticides and fertilizer, but there were two farmer groups developed organic farming systems. The last village already becomes a tourist destination namely Krabyakan Springs, where is always visited, especially in the weekends and holidays. Another study site was Wonorejo Village, a corridor to the Tea Plantation Tourism in Wonosari Village. Three farmer groups in the village have produced the vegetable and livestock in their organic farming system. They produced their own organic fertilizers and natural pesticides from their livestock waste treatment.

Therefore, five farmer groups were selected based on their farming system to provide organic rice, vegetables, fruits, spices and dairy products. Self assessment on existing tourism facilities, policy and performance was conducted by direct observation, site visit, distribution of questionnaire and depth interview with key person of each group. All data were tabulated in Microsoft Excel 2007, descriptively analyzed. Furthermore, gap and SWOT analysis used to compare their profile with a local wellknown agro-tourism in Malang Regency, namely Kusuma Agro-tourism. Based on these gap and SWOT analyses, we proposed some strategies to achieve sustainable agribusiness development.

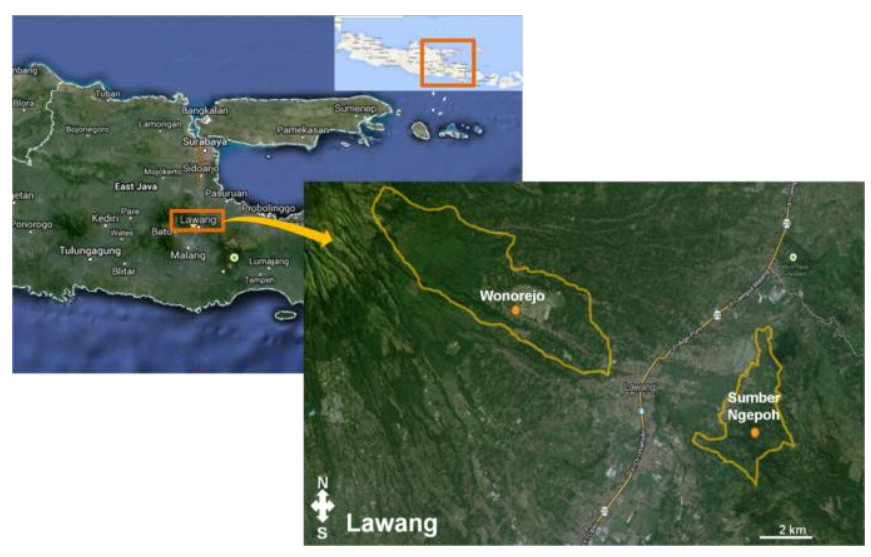

Figure 1. Map of study sites in Lawang 


\section{RESULTS AND DISCUSSION}

Lawang has beautiful view and fresh air therefore many people visit for reason refreshing since colonial era. The beautiful old buildings are well distributed in the village. For this moment, Lawang provides some unique organic agricultural products such as organic perfumed or pigmented rice in Sumber Ngepoh Village, while organic vegetables, fruits and dairy products in Wonorejo Village. Diversified highlow land agriculture commodities are available a long the year, so that Lawang are not only a gateway of Malang to Surabaya but also become a promising tourist destination as well as local people and government may generate in traditional markets and restaurant. Lawang traditional markets provide many vegetables, fruits and many other agriculture products. Unfortunately, most of them are produced from inorganic farming. Now days, tourists from Surabaya or Malang are visit shortly.

\section{Potential Agroedutourism Attractions}

Lawang is known as one of major center for organic agriculture production in Malang. This agriculture is also important links to tourism and introduces environmental education, such as locally grown products, authentic experiences by agricultural heritage and culture as well as enhances the exceptional quality of life. Therefore, Lawang has opportunities to switch agriculture to agroedutourism. Through organic farming practicing, farmer groups had shown farming landscape, scenes and traditional agricultural tools. Based on the five farmer groups' assessment and the gap analysis, it revealed that actually they had offered some different attractions such as livestock farm, organic rice field, fruits and vegetable garden (Fig. 2).

Gap analysis on tourism attractions between agroedutourism in Lawang and Kusuma Agro-tourism were presented in Table 1. Both of tourism presents organic farming system, such as visitors could look around on crops and livestock product using naturally process without chemical fertilizers. However, Lawang provides more varied and complete attractions than Kusuma Agro-tourism. Visitors have a chance to walk around in the rice field or garden to learn a healthy ecosystem and managing agricultural products, food chain, food security, biological pest control as well as ecological and economical benefits of organic farming practice. Moreover, farmer groups also show the suitable process to cultivate rice, fruits and vegetables, therefore the crops grow optimally and produce a good quality yield. Visitors can bring back some vegetable seedlings or purchase seeds to be germ mated at home. Some rice varieties grown were perfumed 'Mentik Wangi' rice, black rice and red rice. In addition, there was diverse of crops and tropical fruits, such as vegetables, cloves, nutmeg, banana, avocado, etc.

Besides that, the organic farming also becomes study site of several colleges who learnt on organic farming, goat breeding, marketing organic products and agro industry. In Sumber Ngepoh, farmer groups present agricultural production processes of plowing, sowing, transplanting, tiling, weeding, irrigation, harvesting, transporting, threshing and grain processing. Other interesting attractions are joining processing black and red cereal, started from washing, drying, cooking, and grinding until packaging. All of these activities were presented by friendly local community.

Farmer groups also presented a variety of educational activities. There are various activities in the livestock such as feeding, capturing picture and milking goat, composting, preparing liquid fertilizer and local microorganism. Some products could be purchased by visitors such as goat's milk ice cream, kefir, body lotion, soap and body scrub from goat's milk. The gap analysis indicating farmer groups in Lawang are able to present seven attractions (Table 1 ). It is a great opportunity for them to develop agroedutourism but they should complete it by creating other attractive and creative activities.

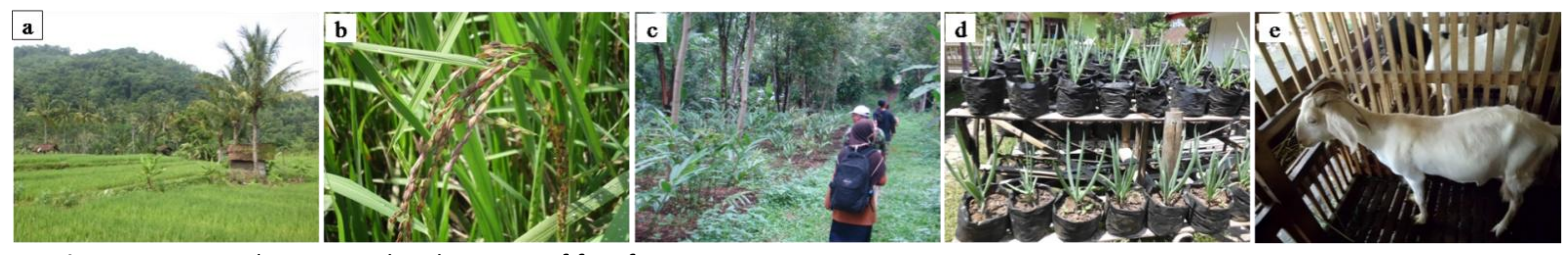

Figure 2. Agroedutourism development of five farmer groups in Lawang. a-b) Local organic perfumed and pigmented rice in Sumber NgepohVillage; c-e) Organic fruits, vegetable garden and goat farm in Wonorejo Village. 
Table 1. Tourist attractions provided by five farmer groups in Lawang based on gap analysis

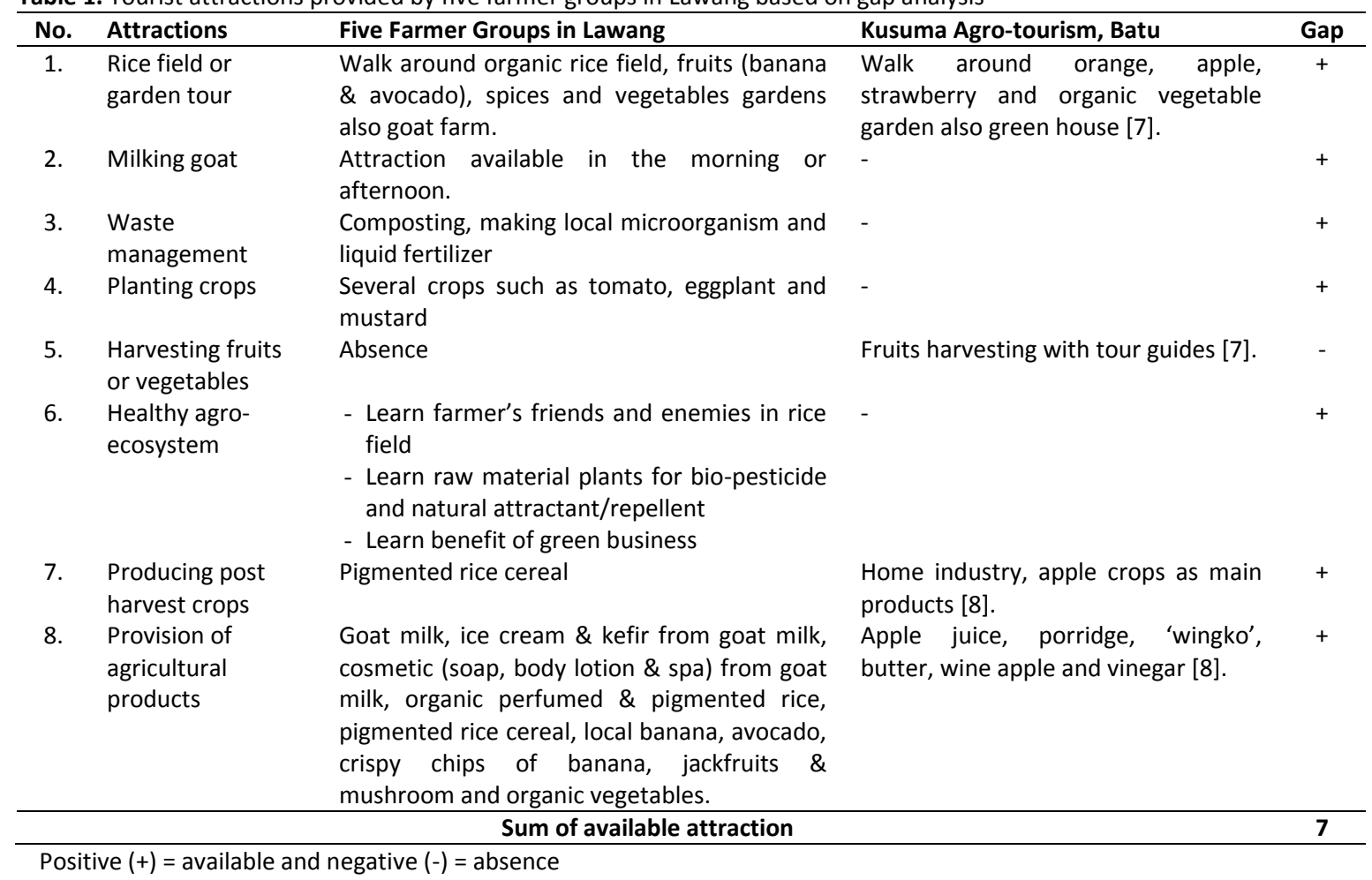

Other attractions that can be presented by farmer groups such as fruits and vegetables harvesting, modified traditional games combined with knowledge of organic farming and practice how to produce a post harvest of agricultural product. Crops variations, enjoyable place and hospitality of local community are expected to increase the visitor satisfaction.

Similar attractions were offered by Bogor Agricultural University that developed the first agroedutourism in Indonesia. Tour packages were designed by utilizing the educational facilities and agricultural resources. The manager offered tourist attractions such as laboratory field trips, experimental gardens, breeding of wild animals (primates, deer and birds), arboretum, lakes and other supporting facilities.

Another tourism garden destination, named Kebun Wisata Pasirmukti (KaWePe), Bogor, also provided similar activities. This tourism had been promoting educational sector for visitors, especially for children and students. The main tour package in KaWePe was 'Agropintar' that prepared based on age of visitors categories. For students, the tour packages adapted with school curriculum. One of facilities at this location was 'House of Farming' which provided the opportunity for visitors to look around the traditional farmhouses and their daily life. Visitors can also interact directly in the
'House of Farming' to learn about feeding livestock, plowing or riding a buffalo. Visitors were expected to get good impression and new experience so they would interest to learn all about agriculture through this packages [9]. In Italy, some National Park develop organic excellence, such as Corte Merina Farm in Val Grande Park, Krauter Schlossl Farm in Stelvio Park, La Quercia della Memoria Farm in Monti Sibillini Park, Rinascita '78 Cooperative in Gran Sasso and Monti della Laga Park, "La Porta dei Parchi" Organic Agritourism in Abbruzzo National Park and Majella National Park, Bio gargano Consortium in Gargano National Park, etc. Each site provides different attractions, traditional products and educational services. It is in order to strengthen the bond between the consumer and the farmers who promote agricultural diversity and rural tourism in National Park. The examples of organic excellence given here demonstrate that organic farming can be a valid way to reconcile the need to protect nature with the production of food and services, and thus income for farmers [10].

\section{Organic Farming as Ecopreneurship}

In their organic fields, farmer groups do not provide only seven attractions but also present some ecopreneurship characters as shown in Table 2. Based on the gap analysis, it is 
known that farmer groups' activities in their organic field are qualified as ecopreneur actions. Agroedu-tourism is an integration of agriculture, edu-cation and tourism component that could be a promising farming enterprise to develop farmer groups business. Firstly, farmer groups provide themselves some eco friendly products such as organic rice, vegetables and fruit, kefir and goat milk, lotion, soap and scrubs from goat's milk and fertilizer. Most of them are supplied to visitors or regular costumer therefore they contribute to organic supply chain and healthy products market.

This food safety does not advantage only to the farmers family but also help many patients of degenerative diseases who need nutritive and hygienic foods. These organic farming activities avoid farmer from health risk of conventional farming. Since the agricultural products are mainly to meet the group members needs while the rest are sold to the community. The Poland conventional farmers were victim of allergic and immunotoxic diseases caused by mold [11]. The other research showed that $37 \%$ of conventional farmers in Bangladesh reported faced frequent health problems such as eye irritation, headaches, dizziness, vomiting, shortness of breath, skin effects and convulsions [12]. Basically, organic farming applied by farmer groups in Lawang does not only serve a healthy food but also share knowledge on preserving a healthy environment. They share good agricultural practices to others so they can initiate similar activities. They also present training service such as prepare natural pesticides and demonstrate organic farming. This training improves participants' knowledge, experience and skills on producing health food by using their own fertilizer and pesticide [13]. Therefore, these activities indicate ecopreneurship characteristics and eco friendly services as reported by Schaltegger [14]. Moreover, organic farming also provides several advantages such as supply a fresh air, preserve soil fertility and water conservation as well as global warming mitigation.

Secondly, organic farming as a food product-ion, did not use synthetic fertilizers and chemical pesticides, would be a part of green economy and support sustainable consumption and production. Farmer groups prepare autonom-ously natural fertilizers or pesticides from local materials such as plants and animals residues as well as microbes, so that they can significantly reduce fertilizer and pesticide cost. A farmer group leader said that he was triggered to reapply organic farming system for reason of economic difficulties due to high price of chemical fertilizers and pesticides. The older people believe that each plant already carries its own fertilizer. Based on this statement, he tried to do small experience. Therefore, he decided applying the traditional farming without using any chemical fertilizers or pesticides. He tried to put straw in the rice fields and to mix it with cow manure. The trials were not immediately success, but to date the farmers harvest rice grain 6-7 tons per hectare.

Table 2. Gap analysis between organic farming five farmer groups and ecopreneur characters

\begin{tabular}{|c|c|c|c|}
\hline No. & Farmer groups activity & Ecopreneur characteristics & Gap \\
\hline 1. & $\begin{array}{l}\text { Farmer groups provide eco friendly products such as } \\
\text { organic rice, vegetables and fruit, kefir and goat milk, } \\
\text { lotion, soap and scrubs from goat's milk, fertilizer, as well } \\
\text { as training services to prepare natural pesticides and } \\
\text { demonstrate organic farming. } \\
\text { - The products fulfill the needs of farmer group members } \\
\text { and then the rest are sold }\end{array}$ & $\begin{array}{l}\text { Supplies eco-friendly products and services } \\
\text { [14]. }\end{array}$ & + \\
\hline 2. & $\begin{array}{l}\text { - Organic farming activities are carried out by minimizing } \\
\text { chemicals use. } \\
\text { - It becomes an effort to reduce carbon emissions by } \\
\text { commodity movement. }\end{array}$ & $\begin{array}{l}\text { The entrepreneurships are not only to make } \\
\text { profits, but also contribute to preserving } \\
\text { the natural environment }[15,16,17,18] \text {. }\end{array}$ & + \\
\hline 3. & $\begin{array}{l}\text { Farmer groups create and use eco friendly products and } \\
\text { become an appreciation of future generation life. }\end{array}$ & $\begin{array}{l}\text { Business behavior are committed to } \\
\text { sustainability }[19,20,21] .\end{array}$ & + \\
\hline 4. & $\begin{array}{l}\text { Each farmer group has the main and complementary } \\
\text { commodities, which reflected their local environmental } \\
\text { resources, as well as based on their socio-cultural values. }\end{array}$ & $\begin{array}{l}\text { Combination of strong environmental and } \\
\text { social value with energetic entrepreneurial } \\
\text { attitude }[22,23]\end{array}$ & + \\
\hline \multicolumn{3}{|c|}{ Sum of ecopreneur characteristics } & 4 \\
\hline
\end{tabular}

Positive $(+)=$ available and negative $(-)=$ absence 
This suggests that agroedutourism as ecopreneurship activity does not only support organic farming to maintain a healthy environment and supply various eco friendly products as reported by Schaltegger [14]. It also ultimately influences in increasing many profits for farmer and their customer. Even yield of organic farming are lower than those of conventional one [24,25]. However organic products price is often higher in the market than the conventional products [26]. Using traditional knowledge, farmers apply organic animal manure or legume intercropping system to improve the low productivity due to nitrogen shortages.

Organic farming becomes promising ecopreneurship activities if it is integrated with tourism sectors. Agroedutourism can be alternative strategy to promote local biodiversity, to sustain rural economy and to protect farmer incomes against market fluctuation. Nevertheless, unlike the other entrepreneur activities, agroedutourism is not only focusing on profitable aspect but it also emphasis on health of human and environment aspects. Almost all of farmer group leaders said that, "If we expect to have lived healthy, so it should be started from the healthy diet". In other words, healthy food from organic farming can be the beginning of a healthy lifestyle. These become a good example for other farmers, because nowadays only a small number of farmer family are aware on food safety and take responsibility to sustainability of healthy environment. In this agroedutourism, farmer groups try to open mind of community that consuming healthy food is very easy. In small scale, it can be provided by home gardening.

Farmer groups also have expectation that local people can be more autonomous in raw material provision and reduce imported products. Thereby it helps reducing carbon emissions due to the international delivery products or services. One of the important things in green business is preserving the natural environment [27,28], therefore environmental impact of organic farming would become attention, such as reduce food exports [25]. Studies in England showed that the transports were accounted for approximately $40-70 \%$ of the carbon footprint of imported plant products transported by ships and or trucks. Another research reported that transport of organic soybean from China to Denmark was contributes half of the carbon footprint [29]. Based on this information, it can be concluded that agroedutourism support sustainable environment and food security by producing locally grown products and minimize the imported organic products.

Thirdly, agroedutourism development also becomes an effort of farmer groups to promote sustainable farming systems to others. Organic farming systems is not only the process of sustainable production and consumption, but also the process to produce and use the product based on needed, bringing a better life quality and minimizing use of natural resources, toxic materials and pollutants emissions over the life cycle. Therefore organic farming did not harmful to the future generations. This concept showed that process of sustainable development has to respect to our life cycle without sacrificing other life cycle. The establishment of agroedutourism in organic farming will provide great advantages such as efficient farming system by zero waste management, increase pest and crop equilibrium by diversification of crop commodity, organization development, national recognizition, a lot of product demand, in farm or off farm training, and give positive image of promising green business for the young generation. Organic agriculture contributes to sustainable development by: 1) Improving soil fertility, biodiversity and sustainability of agricultural production; 2) Conserving natural resources; 3) Improving agronomic and economic performance, making yields more stable, achieve better food quality and food security; 4) Providing access to attractive market; and 5) Creating new partnership within the whole value chain as well as to strengthen self confidence and autonomy of the farmers [30].

Finally, by organic farming development, farmer groups will minimize social imbalance and be more respects to other farmer groups. Since all farmer groups are located in the same regency and they can serve a supply chain, therefore collaboration among them will improve the interesting destination and length of visit. In addition, this collaborative network is important and become a strategy to preserve their professionalism to develop uniqueness commodity against unfair competition as well as to contribute to people education and knowledge based society. Other socio-cultural benefits of agroedutourism such as 1) Creating new jobs and income for themselves and for others, 2) Providing a new tax required by local government for sustainable development of infrastructure, education and human health, 3) Rotating the sustainable economic activities 
including production and marketing, 4) Supporting the birth of new ecopreneurs and involving participation of the community, 5) Becoming a promoter and user of new innovation in producing, managing and marketing of organic products and service. Several studies indicated that, organic farmers should not only be success to provide, but they also might contribute to rural community development by offering significant innovation. For example, they might pay attention to social economy organizations, such as co-operatives and non-profits organization that give them a collective power as well as allow them to protection and advance organic farming [31]. Another advantage from this activity is reducing market chain and increasing customer satisfaction, it shows real benefits of healthy agro-system practices. Therefore, it is needed to improve public awareness of farming activity and concern on ecopreneurship or business.

\section{Agroedutourism Development Profile of Farmer Groups in Lawang}

After farmer groups developed organic farming from almost two decades, they had become benchmarking sites by some stakeholders. The study showed that $80 \%$ of farmer groups were visited regularly 5-10 times per month (Fig. 3) by potential visitors such as other farmer groups, house wives, agricultural staff or students. Indirectly, they provide agroedutourism for their visitors. They learnt how to develop organic farming, marketing and managing organization. This tourism development was supported by a unique and wonderful nature. Moreover, the region show high ecosystem diversity (secondary forest, plantation, wetland, spring, river, home garden and colonial heritage settlement) and potential sites to develop various tourism activities based on integrated organic farming. Therefore, all of farmer groups had planned to develop agroedutourism, however only $60 \%$ or three of five farmer groups issued the policy. Although agroedutourism provides more advantages, there are two farmer groups are not ready to develop the activities in next future. These farmer groups hesitated that mass visitors would disturbed the organic rice fields. Moreover, three farmer groups considered that their facilities are still unqualified to support a comfortable tourist destination.

At the beginning, a leader or a member of farmer groups has a role as tour guides and key person in organic agroedutourism development. Without any formal education, $40 \%$ of farmer groups still not confident and showed a low ability to be tour guide and to prepare guidance material (Fig. 3). It revealed that there are great variations among farmer groups and they have not yet shared formally their experiences to their visitors. Therefore, group member should be more knowledgeable and possess sufficient practical skills and experience before organizing agroedutourism. Meanwhile, talent and competent tours guides are prerequisite in every tourism business. Local human resources who understand the culture and attractions offered are important factors influencing the tourist satisfaction and tourism competitiveness [32, 33]. Enhance of human resource skills could be done by tour guides training, benchmarking to others as well as followed by learning by doing.

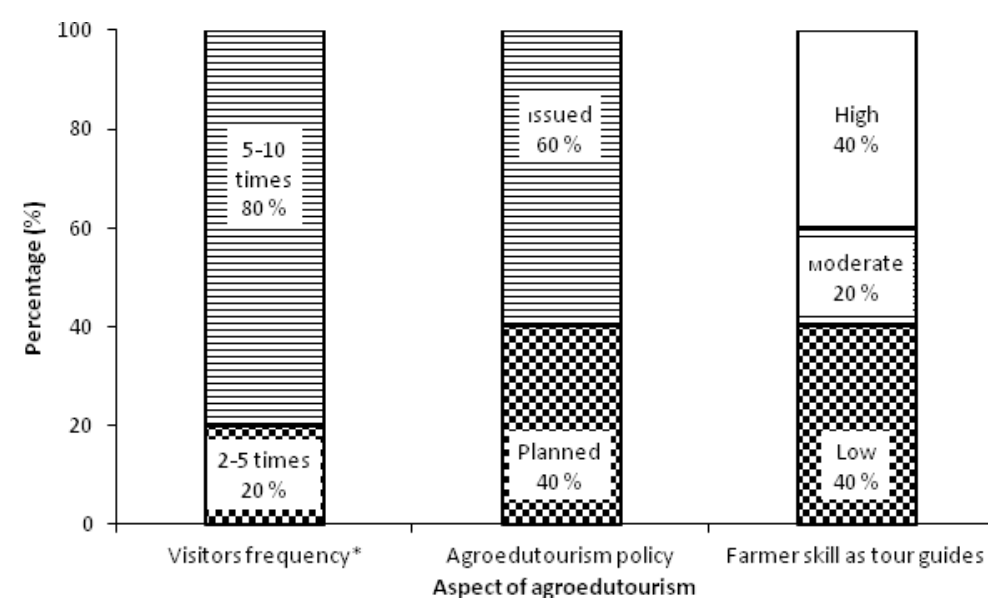

Figure 3. Profile of agroedutourism in five farmer groups * Frequency per month 


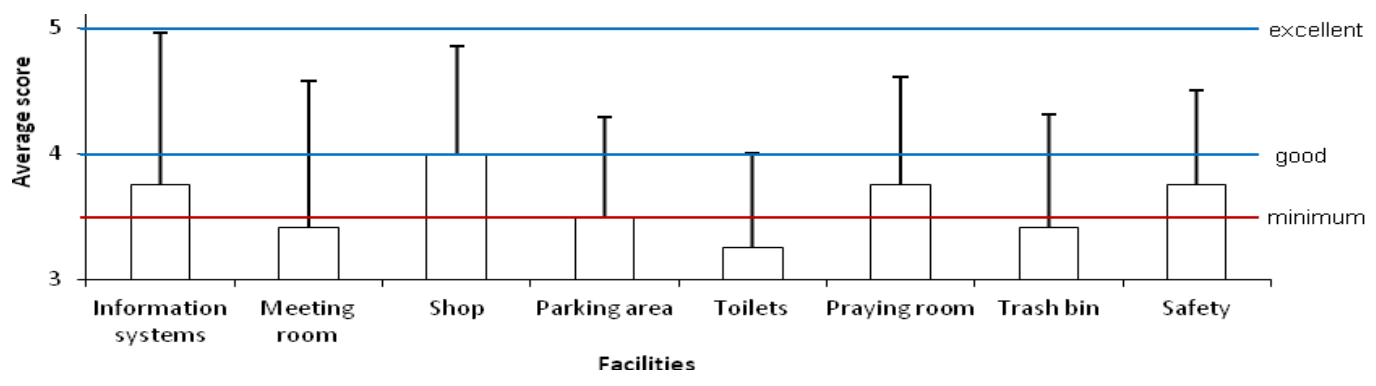

Figure 4. Selves' assessment of five farmer groups in Lawang to perform agroedutourism based on the Lickert's 1-5

Farmer groups completed some facilities to support agroedutourism activities (Fig. 4). But based on the direct observation, we note that parking areas, toilets and trash bin are still absent.

Until now the visitor beneficial for farmer properties. Comparing to a local and well known agro-tourism site, the farmer groups should improve some aspects such as public relation unit, parking area, toilets, trash bin and security systems (Table 3 ). In order to support the long visit tourism and joining more farmers' activities, the farmer groups should notify their visitors in the promotion leaflets some useful information such as contact person, lodgment, tour tracts, schedules, maps, fares, passes, how to ride, travel agents, etc. Public facilities and accessibility are important factors influencing visitors' choice on a tourist destination [34, 35]. Therefore, the lack of facilities or information might cause cancellation and or the visitors turn to another destination. Moreover, some public facilities such as streets, benches, trash bin, parking areas, location maps, signboard, shops, canteens and toilets should be prepared carefully in the tourism development plan [36].

\section{Proposed Strategies for Existing Agroedutourism Development}

Based on farmer group selves' assessment, gap analysis and direct observation as well as SWOT analysis, we note some important findings. One side, they showed some strength to develop the agroedutourism attraction and to support the ecopreneurship indicated by available various attractions of integrated organic farming, eco-friendly products and services, sustainable business, regular visitor and establishment of agroedutourism policy. Another side, however their agroedutourism face some handicaps comprised of no exciting attraction where visitors involve actively such as harvesting fruits, flowers or vegetable, variable tour guides skills, lack of public facilities and weak promotion.

In order to improve the development of agroedutourism in farmer groups we suggest them: 1) To develop some interesting attractions involving directly visitors activities for examples harvesting agricultural products and its post harvest processing to produce health and safe products or educative games; 2) To improve farmer skills as tour guides by establishing training and benchmarking to the better agroedutourism destination, joining internship and developing focus groups discussion (FGD); 3) To complete the facilities, including public relation, parking area, toilets, trash bin and security systems, etc; 4) To collaborate with some relevant farmer groups and stakeholders in Lawang to improve tour tracks and attractions; 5) To promote the agroedutourism to attract more visitors by leaflets, radio, website, exhibition and collaborating with tour agents; 6) To improve hospitality service and commitment of visitor satisfaction by arrange a better agroedutourism governance, regular assessment and management review.

Futhermore, farmer groups should record their milestones to help themselves to focus on goals achievement. Milestones building of green economy for sustainable agribusiness development in Lawang could be programmed into long ( 5 to 20 years) and short term strategies ( 1 to 5 years) (Figure 5). In the short term plan, the program can be run smoothly if the farmer groups involve all elements of the system, focus to their goals achievements, better in managing the visitor feedback, held a management review twice per year to monitor the progress or constraints of each program. 
Table 3. Gap analysis between five farmer groups agroedutourism facilities in Lawang and Kusuma Agrotourism

\begin{tabular}{|c|c|c|c|c|}
\hline No. & Variable & $\begin{array}{c}\text { Existing Condition of } \\
\text { Farmer Groups in } \\
\text { Lawang }\end{array}$ & Kusuma Agro-tourism, Batu & Gap \\
\hline 1. & Public relation & $\begin{array}{l}\text { No tourism unit but it is } \\
\text { handled by the leader. }\end{array}$ & $\begin{array}{l}\text { Marketing, finances and administration, production } \\
\text { of annual crops, production of seasonal crops, agro- } \\
\text { industry, restaurant, entertain and agribusiness } \\
\text { clinic [7]. }\end{array}$ & - \\
\hline 2. & Information system & Name card and leaflets & Leaflets, radio, signboard and web site & + \\
\hline 3. & Meeting rooms & One meeting room & Eight meeting rooms & + \\
\hline 4. & Shops & $\begin{array}{l}\text { Available but limited } \\
\text { products }\end{array}$ & $\begin{array}{l}\text { Shops and home industry with all agriculture } \\
\text { products [7]. }\end{array}$ & + \\
\hline 5. & Parking area & Absence & Available [7] & - \\
\hline 6. & Toilets & Absence & Available [7]. & - \\
\hline 7. & Praying room & $\begin{array}{l}\text { Available, but tap water } \\
\text { is limited. }\end{array}$ & All facilities are available [7]. & + \\
\hline 8. & Trash bin & Absence & Available especially in public place [37]. & - \\
\hline 9. & Security system & Absence & Available [7]. & - \\
\hline 10. & Waste management & Available & Available & + \\
\hline \multicolumn{4}{|c|}{ Positive aspects } & 5 \\
\hline
\end{tabular}

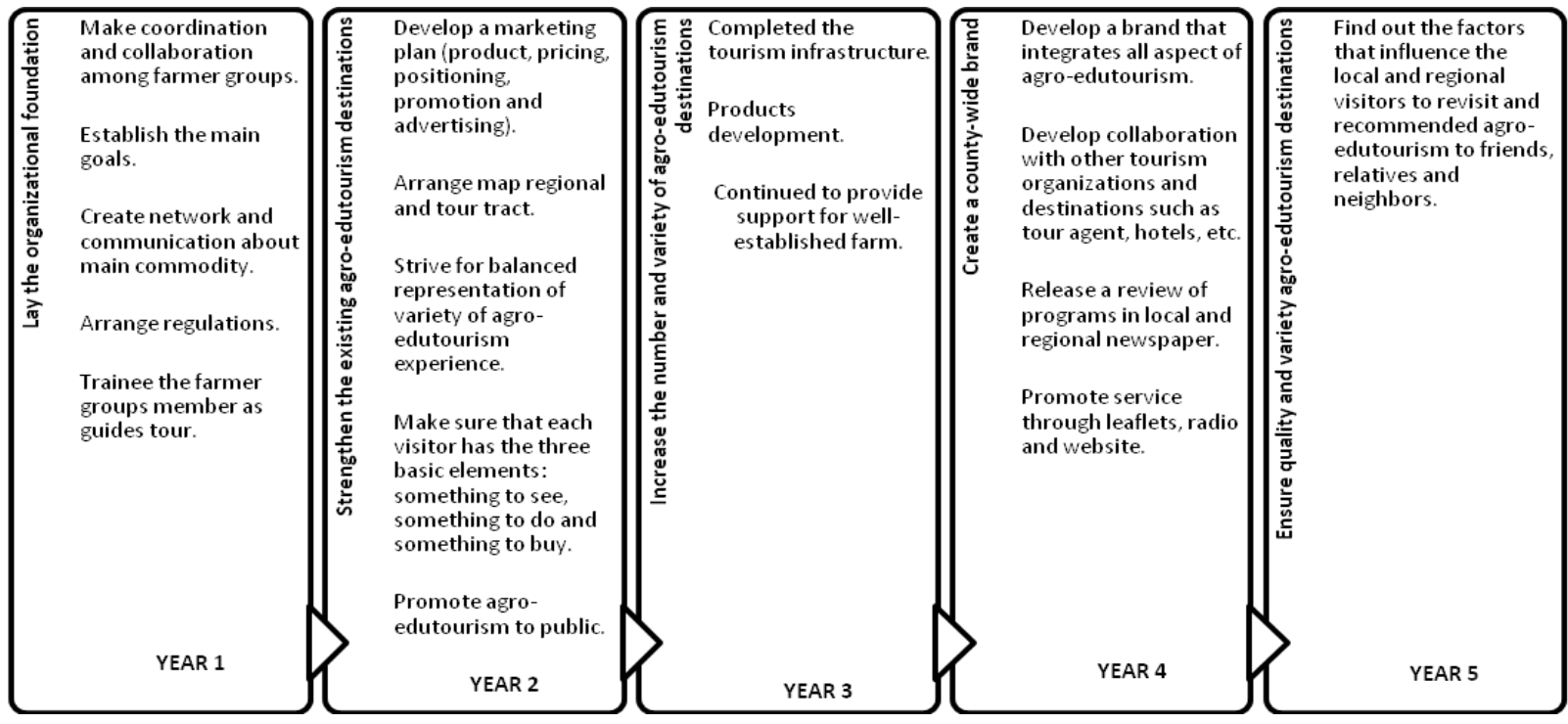

Figure 5. Milestones and strategies to continuous development of agroedutourism farmer groups in Lawang

\section{CONCLUSION}

Five farmer groups in Lawang have shown agroedutourism and ecopreneurship activities in their organic farming daily activity. They provide agroedutourism indicated by some available attractions: walk around the organic garden or the livestock farm, as well as practice organic farming started from preparation to harvest. These agroedutourism activities strengthen farmer ecopreneurship by integrating various attractions into organic farming, providing ecofriendly products or services, and finally establishing policy to support green business. Unfortunately, to date their performance still limited due to some weaknesses such as lack of the exciting tourist attraction, variable tour guides skills, public facilities and effective promotion. Therefore, in order to enhance their agroedutourism activities and ecopreneurship quality, we suggest that farmer groups continuously improve their performance by better managing human, natural resources and services.

\section{ACKNOWLEDGMENT}

Author would like to thank you all organic farmer groups in Lawang for share information, all of college and staff Ecology and Animal Diversity Laboratory, Biology Department, Faculty of Mathematic and Natural Science, Brawijaya University, Malang for spirit during research. 


\section{REFERENCES}

[1] Sass, S. B. 2012. Environmental impacts of agriculture: conventional and organic farming systems. Public in Review 1 (1), 3844.

[2] Diepeningen, A. D., O. J. Vos, G. W. Korthals and A. H. C. Bruggen. 2006. Effects of organic versus conventional management on chemical and biological parameters in agricultural soils. Applied Soil Ecology 31 (2), 120-135.

[3] Chin, F. S., T. Y. Ho, K. P. Chong, M. B. Jalloh and N. K. Wong. 2010. Organic versus conventional farming of tea plantation. BorneoScience 26, 19-26.

[4] Ministry of Agriculture. 2010. Strategic planning of Ministry of Agriculture 20102014. Jakarta.

[5] Melero, S., J. C. R. Porras, J. F. Herencia and E. Madejon. 2006. Chemical and biochemical properties in a silty loam soil under conventional and organic management. Soil and Tillage Research 90 (2), 162-170.

[6] Sub-district Government of Lawang. 2014. Selayang Pandang. www.lawang.malangkab. go.id. Accesed on 3 April 2014.

[7] Priambodo, R. 2007. Analysis of performance assessment to measure the satisfaction level of consumer in Kusuma Agro Tourism, Batu Malang. Thesis. Faculty of Economy, University of Jember. Jember.

[8] Andria, F. 2010. Revitalisasi Pemasaran Produk Apel Olahan dan Implikasinya Terhadap Strategi dan Bauran Pemasaran PT Kusuma Satria Dinasari WisatajayaMalang. Jurnal Unida, 1 (1): 38-49.

[9] Rokhman, M. 2008. Analysis of promotion strategies Agrotourism in Tourism Garden of Pasirmukti Citeureup, Bogor. Thesis. Study Program of Agribusiness Management, Faculty of Agriculture, Bogor Agricultural University. Bogor.

[10] Grandi, C. \& A. Triantafyllidis. 2010. Organic Agriculture in Protected Areas, The Italian Experience. Natural Resources Management and Environment Department. Food and Agriculture Organization of the United Nations.

[11] Zukiewicz-Sobczak, W., G. Cholewa, E. Krasowska, J. Zwolinski, P. Sobczak, K. Zawislak, J. Chmielewska-Badora, J. Piatek, A. Wojtyla. 2012. Pathogenic fungi in the work environment of organic and conventional farmers. Postepy Dermatologii i Alergologii XXIX (4), 256-262.

[12] Dasgupta, S., C. Meisner and D. Wheeler. 2004. Is environmental-friendly agriculture less profitable for farmers? evidence on itegrated pest managemnet in bangladesh. World Bank Policy Research Working Paper, 3417.

[13] Nisa', A.R.K., S. Samino and E. Arisoesilaningsih. 2014. Organic agroedutourism attractions toward an interesting outdoor environmental education to junior high school students. Journal of Tropical Life Science 4 (2).

[14] Schaltegger, S. 2002. A Framework for ecopreneurship: leading bioneers and environmental managers to ecopreneurship. Greener Management International 38, 4558.

[15] Pastakia, A. 1998. Assessing ecopreneurship in the context of a developing country: the case for India. Greener Management International 38, 93-108.

[16] Volery, T. 2002. Ecopreneurship: Rationale, Current Issues and Future Challenges. In U. Figlisteraller, H. J. Pietner, T. Volery, W. Weber (Eds). Radical change in the world: will SMEs soar or crash? KMU Verlag: St. Gallen.

[17] Walley, E. E. L. and D. W. D. Taylor. 2002. Opportunities, champions, mavericks? a typology of green entrepreneurs. Green Management International 38, 31-43.

[18] Schaper, M. 2005. Understanding the Green Entrepreneur. In M. Schaper (Eds). Making ecopreneurs: developing sustainable entrepreneurship $2^{\text {nd }}$ Edition. Gower Publishing Limited: Farnham.

[19] Isaak, R. 2002. The making of the ecopreneur. Greener Management International 38, 81-91.

[20] Schnick, H., S. Marxen and J. Freiman. 2002. Sustainability issues for startup entrepreneurs. Greener Management International 38, 59-70.

[21] Kirkwood and Walton. 2010. What motivates ecopreneurs to start businesses? International Journal of Entrepreneurial Behaviour and Research 16 (3), 204-228.

[22] Anderson, A. R. 1998. Cultivating the garden of eden: environmental entrepreneuring. Journal of Organizational Change Management 11 (2), 135-144.

[23] Gibbs, D. 2009. Sustainability entrepreneurs, ecopreneurs, and the development 
of a sustainable economy. Greener Management International 55, 63-78.

[24] Ghorbani, R., A. Koocheki, M. Jahan and G.A. Asadi. 2008. Impact of organic amendments and compost extracts on tomato production and storability in agroecological systems. Agronomy for Sustainable Development 28, 307-311.

[25] Seufert, V., N. Ramankutty and J. A. Foley. 2012. Comparing the yields of organics and conventional agriculture. Nature 485, 229232.

[26] Pimentel, D., P. Hepperly, J. Hanson, D. Douds and R. Seidel. 2005. Environmental, energetic, and economic comparison of organic and convential farming systems. BioScience 55 (7), 573-582.

[27] Piekarski, C. M., L. M. da Luz, L. Zocche and A. C. de Francisco. 2013. Life cycle assessment as entrepreneurial tool for business management and green innovations. Journal of Technology Managemnet and Innovation 8 (1), 44.53.

[28] Chopra, K. 2014. Ecopreneurship: Is it a viable business model? AE International Journal of Multidisciplinary Research 2 (3), 1-6.

[29] Knudsen, M. T., Q. Y. Hui, L. Yan, G. F. de Almeida, L. S. de Abreu, N. Halbergand and V. Langer. 2011. Transport is important in the carbon footprint of imported organic plant products. International Centre for Research in Organic Food Systems (ICROFS) News 2, 4-7.

[30] Kilcher, L. 2007. How organic agriculture contributes to sustainable development. University of Kassel at Witzenhausen JARTS, Suplement, 29, 31-49.

[31] Sumner, J. and S. Liewelyn. 2009. Fact sheet: building stronger communities organic farmers and the social economy. http://socialeconomycentre.ca/PDF/factshe ets/orgfarmers.pdf. Accesed on 1 July 2014.

[32] Kusluvan, S., Z. Kusluvan, I. Ilham and L. Buyruk. 2010. The human dimension: a review of human resources management issues in the tourism and hospitality industry. Cornell Hospitality Quarterly 50 (2), 171-214.

[33] Milic, V. J., S. Jovanovic and B. Krstic. 2011. Human resources in tourism as a factor of its employment and competitiveness growth-comparative analysis of Serbia and surrounding countries. Facta Universitatis
Series Economics and Organization 8 (4), 433-445.

[34] Ferdiansyah, F. 2005. Estimation and influence factors on visit to Little Farmers Agrotourism Farm Unit of Employee Cooperative in PT. Bio Farma Cisarua, Lembang. Thesis. Study Program of Business Management, Faculty of Agriculture, Bogor Agricultural University, Bogor.

[35] Al Muttaqien, A. 2007. Analysis on competitive strategies on Agrotourism of Vin's Berry Park of Jambudipa Village, Cisarua-Lembang Sub-district, Bandung Regency, West Java. Thesis. Study Program of Business Management, Faculty of Agriculture, Bogor Agricultural University, Bogor.

[36] Sopha, C. 2009. Ban Khmer and Ban Yuan. Villages: a model for ethnic community for tourism development as a secondary attraction in Bangkok. Thesis Program of Architectural Heritage Management and Tourism. Silpakorn University. Bangkok.

[37] Dimpudus, Y. A. 2012. Open spatial planning of fruit pick agrotourism area in Batu based on visitors' comfortness. Thesis. Department of Architecture Engineering, Faculty of Engineering, University of Brawijaya. Malang. 